A $4.4: 92$

U. S. DEPARTMENT OF AGRICULTURE,

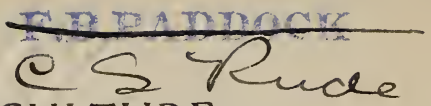

BUREAU OF ANIMAL INDUSTRY.-CIRCULAR NO. 92.

A. D. Melvin, Chief of Bureau.

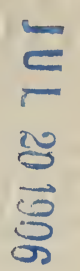

\title{
THE POULTRY INDUSTRY OF PETALUMA, CAL.
}

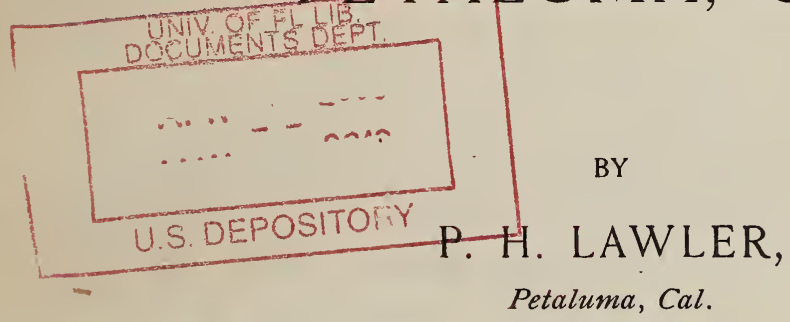

[Reprinted from the Twenty-first Annual Report of the Bureau of Animal Industry (1904).]

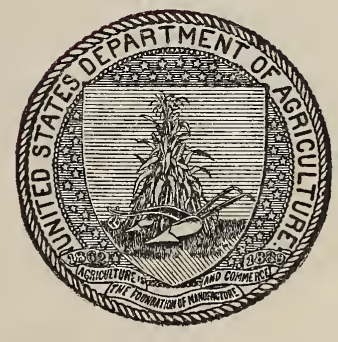

WASHINGTON :

GOVERNMENT PRINTING OFFICE.

1906. 


\title{
The Poultry indestry of petaluma, cal.
}

\author{
By P. H. Lawler,
}

Petaluma, Cal.

\section{THE INDUSTRY THROUGHOUT THE STATE.}

There are no records which show the beginning of the poultry industry of California. Certainly poultry were here as early as 1850, when immigrants brought them " across the plains" from "the States" for foundation stock upon the new farms to be opened or in the mining districts. Gold mining absorbed the attention of all men in those days, and the preservation of the chicken industry devolved therefore upon the women and children. It was many years later before a gold mine was discovered in the chicken industry.

It must not be understood that all parts of the State are equally well adapted for poultry raising. The raising of chickens, for instance, is not generally a paying business except upon a strip 40 miles wide along the Pacific. Turkeys, however, thrive in all parts of the State, and the counties of Mendocino, Colusa, Glenn, Tehama, and Lake are regarded as the turkey center. In these counties it is not unusual for one to see flocks of turkeys ranging in number from 2,000 to 5,000 . Grain is produced in this section in large quantity and feed is consequently comparatively cheap. The turkeys of Mendocino and Lake counties have a reputation for their excellent table qualities, and thousands of them are annually marketed in all sections of the State. The high, dry ranges in the foothills afford excellent runs for turkeys. Geese and ducks are found in every part of the State.

PETALUMA A POULTRY CENTER.

The year 1889 found many people engaged exclusively in the poultry business in Sonoma County, especially in the neighborhood of the town of Petaluma. This town, which has a population of about 5,000, is 36 miles in a northerly direction from San Francisco, on an arm of San Pablo Bay. The surrounding cities, including San Francisco, have a combined population of 600,000 , and all these draw 
largely upon the Petaluma district for eggs and poultry. The soil, except east of the town, is of a sandy loam, in some places containing clay and gravel. East of the town the soil is adobe, and on this the chickens do not thrive well. Shade and good water are everywhere abundant. From May to October there is no rain; a few frosts occur in December and January; there is never snow and ice. In the wet season the temperature is usually from $60^{\circ}$ to $65^{\circ} \mathrm{F}$.; occasionally it drops in winter to $35^{\circ}$ to $40^{\circ} \mathrm{F}$. In the summer the temperature usually is about $70^{\circ}$, but some times, for a fèw days only in a season, it reaches $95^{\circ} \mathrm{F}$. The annual rainfall is about 30 inches.

A few years ago the land about Petaluma was in stock and dairy farms, but all this is now devoted also to poultry. About nine-tenths of the people who are living near the town are engaged in raising poultry. In the town itself there may be found a few hens in every back yard. In the suburbs there are on acre lots from 600 to 1,000 fowls. Farther out, a mile or two from the town, the tracts contain from 3 to 10 acres; 4 or 5 miles out the farms are from 10 to 100 acres in extent; and at a distance of 10 to 15 miles there are poultry farms of 500 to 600 acres. There is a small valley about 3 miles from the city where there are 40,000 laying hens on a single square mile, not to mention the hundreds of thousands of chicks that are hatched there every year.

In this connection it is interesting to note that in the immediate vicinity of Petaluma there are 1,000,000 laying hens. If it were possible to add to this the number of males employed and the number of chickens sold annually an idea would be had of the very great number in that locality.

It will be very natural for readers of this article to desire to know what the income is from a given number of hens. Of course, egg and poultry production is li're any other business in that the one who knows his work best and attends to it most assiduously is the one who succeeds in marked degree. As an example of what may be done in one year with 500 hens, the following tabular statement is given. The prices are such as have obtained in this locality:

\begin{tabular}{rr}
3,723 dozen eggs, at $31 \frac{1}{2}$ cents & $\$ 1,170.75$ \\
145 broilers, at $42 \frac{1}{2}$ cents & 61.62 \\
Tollets, at 50 cents & 100.00 \\
Cost of feed & $1,332.37$ \\
$\quad$ Profit & 400.00 \\
\hline
\end{tabular}

It should be stated, however, that the poultry raisers of Petaluma expect an average annual income of $\$ 1$ per hen only. 


\section{SHIPMENTS OF POULTRY AND EGGS.}

In 1889, when the poultry business of Petaluma first came into prominence, one of the leading expressmen says he was doing well when he handled 50 cases (a case equals 36 dozens) of eggs per day. At the present time he handles from 200 to 300 cases a day. Other expressmen give similar experiences.

Fowls are shipped alive in coops of wooden frames having wire rods or heavy hexagonal-mesh wire netting. Eggs are shipped in an especially heavy case holding 36 dozens.

The following statement of the sales of eggs and poultry at Petaluma is from the daily records kept by the Petaluma Poultry Journal of that place:

Shipments of poultry and eggs for the year 1908.

\begin{tabular}{|c|c|c|c|c|c|}
\hline Month. & Eggs. & Poultry. & Month. & Eggs. & Poultry. \\
\hline January & $\begin{array}{r}\text { Dozens. } \\
96,485\end{array}$ & $\begin{array}{r}\text { Dozens. } \\
1,301\end{array}$ & August ... & $\begin{array}{l}\text { Dozens. } \\
197,635\end{array}$ & $\begin{array}{r}\text { Dozens. } \\
3,582\end{array}$ \\
\hline February & 258,164 & 1,698 & September . . & 195,954 & 3,959 \\
\hline March & 562,258 & 1,479 & October & 127,254 & 2,486 \\
\hline April....... & 558,048 & 2,362 & November ..... & 95,966 & 2,615 \\
\hline May & 448,782 & 1,780 & December...... & 135,039 & 1,875 \\
\hline June - ....... & - 447,996 & 5,006 & Total .. & $3,406,335$ & $\overline{31,545}$ \\
\hline July & 242,754 & 3,392 & & & \\
\hline
\end{tabular}

These products are all marketed in San Francisco-some to go into the mining districts, but much the greater part goes to fill Government orders and for shipment on steamers for Alaska, Hawaii, and the Philippines.

In Petaluma there are twelve firms dealing exclusively in poultry and eggs, as well as branches of two larg a commission houses of San Francisco. These houses pay out about $\$ 3,000$ a day for poultry and eggs.

Incidentally let it be stated that San Francisco receives poultry products, in addition to those from Petaluma and other parts of the State, to the value of $\$ 1,500,000$ annually. These products are called " eastern " as distinguished from "coast." The eastern eggs received in 1903 amounted to 824,648 dozens. In 1904 they increased to $1,109,160$ dozens.

The following table shows the average prices of eggs in the San Francisco market for the years of 1903 and 1904 and the amount of coast eggs received for the same years. 
Average prices and quantity of eggs received in San Francisco, 1903 and 1904.a

\begin{tabular}{|c|c|c|c|c|}
\hline \multirow{2}{*}{ Week ended- } & \multicolumn{2}{|c|}{$\begin{array}{c}\text { Prices of egge per } \\
\text { dozen. }\end{array}$} & \multicolumn{2}{|c|}{$\begin{array}{l}\text { Receipts of coast } \\
\text { eggs. }\end{array}$} \\
\hline & 1903. & 1904. & 1903. & 1904. \\
\hline January 7 ... & $\begin{array}{r}\text { Cents. } \\
30\end{array}$ & $\begin{array}{r}\text { Cents. } \\
35\end{array}$ & $\begin{array}{l}\text { Cases. } \\
\qquad 3,170\end{array}$ & $\begin{array}{l}\text { Cases. } \\
3,681\end{array}$ \\
\hline January 14 & $30 \frac{1}{2}$ & 31 & 3,618 & 5,161 \\
\hline January 21 & $30 \frac{1}{2}$ & 27 & 3,674 & 5,847 \\
\hline January 28 & $31_{\frac{1}{2}}$ & 25 & 3,880 & 5,592 \\
\hline February 4 & $34 \frac{1}{2}$ & 26 & 5,702 & 6,049 \\
\hline February $11 \ldots$ & $35 \frac{1}{2}$ & $26 \frac{1}{2}$ & 5,532 & 6,807 \\
\hline February $18 \ldots$ & 34 & $25 \frac{1}{4}$ & 6,153 & 6,709 \\
\hline February 25 & $33 \frac{1}{2}$ & $24 \frac{1}{2}$ & 7,320 & 6,508 \\
\hline March 3 & 29 & $20 \frac{1}{2}$ & 9,511 & 8,883 \\
\hline March 10 & 26 & 17 & 9,148 & 8,791 \\
\hline March 17 & 25 & 17 & 10,029 & 8,914 \\
\hline March 24 & $25 \frac{1}{2}$ & 20 & 10,180 & 9,691 \\
\hline March 31 ...... & 25 & 21 & 11,908 & 9,834 \\
\hline April 7 & 24 & $19 \frac{1}{2}$ & 11,974 & 9,375 \\
\hline April 14...... & 22 & 19 & 11,132 & 9,508 \\
\hline April $21 \ldots$ & 21 & 19 & 10,540 & 8,538 \\
\hline April $28 \ldots$ & 21 & $19 \frac{1}{2}$ & 11,667 & 10,026 \\
\hline May 5 & 21 & $21 \frac{1}{2}$ & 11,577 & 9,633 \\
\hline May $12 \ldots \ldots$ & $21_{\frac{1}{2}}$ & $21_{2}^{\frac{1}{2}}$ & 11,175 & 9,088 \\
\hline May 19 & 24 & $19 \frac{1}{2}$ & 11,445 & 9,261 \\
\hline May 26................... & $23 \frac{1}{2}$ & 19 & 10,586 & 9,603 \\
\hline June 2 & 23 & 19 & 8,057 & 9,251 \\
\hline June 9 & 24 & $21_{2}^{\frac{1}{2}}$ & 8,422 & 8,722 \\
\hline June 16 & 25 & 23 & 8,146 & 8,533 \\
\hline June 23 & 25 & 23 & 7,128 & 7,465 \\
\hline June 30 & $24 \frac{1}{2}$ & $22 \frac{1}{2}$ & 8,369 & 7,962 \\
\hline July $7 \ldots \ldots$ & $24 \frac{1}{2}$ & 23 & 6,480 & 6,912 \\
\hline July 14 & $25 \frac{1}{2}$ & 26 & 6,190 & 8,473 \\
\hline July 21 & $26 \frac{1}{2}$ & 28 & 6,221 & 8,110 \\
\hline July $28 \ldots \ldots$ & $25 \frac{1}{3}$ & $25 \frac{1}{2}$ & 5,080 & 8,388 \\
\hline August 4 & $24 \frac{1}{2}$ & 26 & 5,241 & 8,034 \\
\hline August 11. . . & 25 & 26 & 4,796 & 5,363 \\
\hline August 18............ & 27 & 29 & 4,347 & 4,680 \\
\hline August 25 & 28 & $30 \frac{1}{2}$ & 3,727 & 4,417 \\
\hline September 1....... & 29 & 33 & 4,561 & 4,011 \\
\hline September 8 & 29 & 35 & 2,388 & 3,533 \\
\hline September 15 & 30 & 35 & 4,015 & 4,337 \\
\hline September 22 & 31 & 37 & 3,488 & 3,549 \\
\hline September 29 & 30 & 40 & 3,445 & 3,732 \\
\hline October 6 & $28 \frac{1}{2}$ & 39 & 3,334 & 3,507 \\
\hline October 13 & $27 \frac{1}{2}$ & $39 \frac{1}{3}$ & 3,598 & 3,235 \\
\hline October 20 & $28 \frac{1}{4}$ & 40 & 3,439 & 3,373 \\
\hline October 27 & 29 & $41 \frac{1}{2}$ & 3,886 & 3,193 \\
\hline November 3 & 30 & $43^{\frac{1}{4}}$ & 3,977 & 3,231 \\
\hline November 10 & $31_{2}^{\frac{1}{2}}$ & 48 & 3,685 & 3,005 \\
\hline November 17 & $32 \frac{1}{2}$ & $48 \frac{1}{2}$ & 3,609 & 3,398 \\
\hline November 24 & 32 & $43 \frac{1}{2}$ & 3,635 & 3,075 \\
\hline December 1 . & 30 & 39 & 3,671 & 3,518 \\
\hline December 8 & $28 \frac{8}{4}$ & 38 & 3,701 & 2,802 \\
\hline December 15 & $27 \%$ & $39 \frac{1}{2}$ & 3,827 & 2,781 \\
\hline December 22 & 26 & 40 & 3,920 & 2,816 \\
\hline December 29 & 26 & 40 & 4,141 & 3,028 \\
\hline Total .................. & $\cdots$ & --- & 328,445 & 323,933 \\
\hline
\end{tabular}

a These statistics are from Dairy Produce and Review.

H. Doc. $467,58-3-22$ 
Thus we see that the coast eggs received on the San Francisco market in 1904 amounted to $11,661,588$ dozens. The importance of Petaluma as an egg-producing center is strikingly apparent when we subtract her output of $3,406,335$ dozens in 1904 from the above, leaving a balance of $8,255,253$ dozens for all the rest of the State.

BREEDS OF CHICKENS IN USE.

The breeds of chickens that form the basis of this large industry in the vicinity of Petaluma are as follows: Barred Plymouth Rocks, Brown Leghorns, White Leghorns, and a few other varieties in small numbers. However, the White Leghorns soon demonstrated their special adaptability for the conditions obtaining in this locality, and they now predominate in an overwhelming degree; in fact, it is said that the vicinity of this town is called one vast White Leghorn farm.

\section{METHOD OF HATCHING AND RAISING.}

The hatching and raising of the chickens is practically all done by artificial methods. Not one one-hundredth of 1 per cent is now hatched by the hen. Artificial incubation is so important that a large incubator plant is located at Petaluma. In order to demonstrate the fitness of the hatching machine, this factory conducts a hatchery in which 2,500 eggs are always in course of incubation. On December 16, 1904, 9,000 chicks were hatched in one incubator establishment in Petaluma.

There is here a chicken hatchery which is believed to be the largest in the world. It consists of an incubator house in which 30,000 eggs are in all stages of incubation; two houses, each 300 feet in length, and each having a capacity of 2,500 laying hens; and two brooder houses, each 160 feet in length, and having a combined capacity of 100,000 broilers a year. In this plant a ton of feed is used at each feeding time. Electric cars are used in the buildings for carrying feed and wash water and for collecting the eggs and the offal. The daily gathering of eggs is about 3,600 .

The feed is all stored in the upper floor and is delivered into the feed troughs by means of chutes. Water is furnished by a system of pipes to each pan. The floors are all of concrete, and the whole institution may be whitewashed in three hours by the use of machinery.

When the chickens are ready to be removed from the incubator they are transferred to brooding houses, where they are placed in small individual hot-air brooders having a capacity equal to 1,000 chicks. When the chicks graduate from the brooders they are placed in small houses and taught to use the perch. Here they 
remain until the sexes are separated and the cockerels are marketed. There are no yards in connection with some brooding houses, while there are extensive ones in connection with others.

A' large quantity of the feed is of mixed grains ground and sold as a balanced ration, wheat being the standard feed. Whole corn is used in the winter months, but none in the summer. The ground product is given to the chicks. The corn used comes in carload lots from eastern States.

\section{COLD STORAGE FOR EGGS.}

There is located at Petaluma a cold-storage plant with a capacity for 10,000 cases $(360,000$ dozens) of eggs. In one day in 1903 this plant paid out $\$ 3,529$ for 16,927 dozens of eggs. It has been ascertained here that the average loss of eggs placed in cold storage amounts to the very small number of 2 for each case of 36 dozens.

\section{THE TURKEY INDUSTRY OF CALIFORNIA.}

The following information about the turkey industry in California is furnished by Mr. Ed. Hart, of Clements, Cal.:

The turkey industry of this State is becoming a very important one: During the last two years the demand has exceeded the supply. Turkeys have been grown here for over thirty years, but the demand has never before been so steady and the prices so remunerative as at present. The demand is especially large at Thanksgiving and Christmas times. During these holiday seasons the San Francisco receipts are from 250 to 300 tons. Besides, Oregon sends from 20 to 40 tons more, and from 50 to 70 tons come from the East. The largest receipts of California turkeys were formerly from the southern part of the State, but now they are from the northern part, the largest producing counties being Colusa, Glenn, Tehama, Mendocino, and Lake.

The prices that have been paid for turkeys in the San Francisco market during each week of 1903 and 1904 are shown in the following table, which has been compiled for use here by J. Zentner \& Co., of San Francisco:

Prices of turkeys in 1903 and 1904.

\begin{tabular}{|c|c|c|c|c|c|c|c|}
\hline \multirow{2}{*}{ Date. } & \multicolumn{2}{|c|}{ Live. } & \multirow{2}{*}{ Dressed. } & \multirow{2}{*}{ Date. } & \multicolumn{2}{|c|}{ Live. } & \multirow{2}{*}{ Dressed. } \\
\hline & Grown. & Young. & & & Grown. & Young. & \\
\hline $\begin{array}{r}1903 . \\
\text { January } 3 . .\end{array}$ & $\begin{array}{l}\text { Cents. } \\
17-18\end{array}$ & Cents. & $\begin{array}{l}\text { Cents. } \\
20-22\end{array}$ & $\begin{array}{c}1903 . \\
\text { March } 14 \ldots\end{array}$ & $\begin{array}{l}\text { Cents. } \\
\text { 15-17 }\end{array}$ & Cents. & $\begin{array}{l}\text { Cents. } \\
18-20\end{array}$ \\
\hline January 10 & $17-18$ & & $21-23$ & March 21 & $15-17$ & & $18-20$ \\
\hline January 17 & $17-18$ & & $21-23$ & March 28 & $15-17$ & & $18-20$ \\
\hline January 24 & $17-18$ & & $19-21$ & April 4 & $15-17$ & & \\
\hline January 31 & $17-18$ & & $20-22$ & November 7 & & & $20-23$ \\
\hline February 7 & $17-18$ & & $20-22$ & November 14 & & & $20-24$ \\
\hline February 14 & $17-18$ & & $20-22$ & November 21 & & & $21-24$ \\
\hline February 21 & $16-18$ & & $18-20$ & November 28 & $20-22$ & & $22-25$ \\
\hline February 28 & $15-17$ & & $18-20$ & December 5 & 21-23 & & $25-28$ \\
\hline March $7 \ldots$ & $15-21$ & & $18-20$ & December 12 & $19-22$ & & $20-23$ \\
\hline
\end{tabular}


Prices of turkeys in 1903 and 1904-Continued.

\begin{tabular}{|c|c|c|c|c|c|c|c|}
\hline \multirow{2}{*}{ Date. } & \multicolumn{2}{|c|}{ Live. } & \multirow{2}{*}{ Dressed. } & \multirow{2}{*}{ Date. } & \multicolumn{2}{|c|}{ Live. } & \multirow{2}{*}{ Dresssed. } \\
\hline & Grown. & Young. & & & Grown. & Young. & \\
\hline $\begin{array}{c}1903 . \\
\text { December } 19\end{array}$ & $\begin{array}{r}\text { Cents. } \\
19-21\end{array}$ & Cent & $\begin{array}{l}\text { Cents. } \\
20-22\end{array}$ & $\begin{array}{r}1904 . \\
\text { June } 18 . \ldots\end{array}$ & $\begin{array}{r}\text { Cents. } \\
14-15\end{array}$ & Cents. & Cents. \\
\hline December 25 & $18-20$ & & $20-23$ & July 2 & 14-15 & & \\
\hline 1904. & & & & July 9 _.. & $14-15$ & & \\
\hline January 1 & $16-18$ & & $18-22$ & July 16 . & $14-15$ & & \\
\hline January 9 & $18-20$ & & $22-25$ & July 23 . & $14-15$ & & \\
\hline January 23 & $14-16$ & & $17-20$ & July 30 . & $15-17$ & & \\
\hline January 30 & $15-17$ & & $18-20$ & August 6 & $15-17$ & $24-25$ & \\
\hline February 6 & $15-17$ & & $18-20$ & August & $15-17$ & 24-25 & \\
\hline February 13. & $15-17$ & & $18-21$ & August 2 & $15-17$ & 24-25 & \\
\hline February 2 & $15-17$ & & $18-21$ & August $27 .$. & $15-17$ & $20-25$ & \\
\hline February 27 & $15-17$ & & $18-21$ & September 3 & $14-15$ & $20-22$ & \\
\hline March 5 & $16-17$ & & $16-21$ & September 9 & $14-15$ & $20-22$ & \\
\hline March 12 & $16-18$ & & $18-22$ & September 1 & $14-15$ & $20-22$ & \\
\hline March 19 & $16-18$ & & $18-22$ & September 2 & $14-15$ & $20-22$ & \\
\hline March 26 & $16-18$ & & $18-22$ & October 15 & $14-15$ & $18-22$ & \\
\hline April 2... & $18-18$ & & $18-22$ & October 22 & $14-16$ & $20-22$ & \\
\hline April 9.... & $16-18$ & & $18-22$ & October 29 & $14-15$ & $20-22$ & - \\
\hline April 16.... & $16-18$ & & $18-22$ & Novembe & $15-18$ & $21-23$ & \\
\hline April 23... & $15-17$ & & $16-18$ & Novem & $17-20$ & 20-22 & $23-25$ \\
\hline April $30 \ldots$ & $15-17$ & & $18-20$ & November 1 & $17-20$ & $20-22$ & $20-26$ \\
\hline May 7..... & $14-15$ & & $18-20$ & November 2 & $14-15$ & & $12 \frac{1}{2}-18$ \\
\hline May $14 \ldots$ & 14-15 & & $18-20$ & December 3 & $15-17$ & & $18-23$ \\
\hline May $21 \ldots$ & $14-15$ & & $18-20$ & December 10 & $16-18$ & & $22-25$ \\
\hline May 28.... & $14-15$ & & $18-20$ & December 17 & $18-20$ & & $20-22$ \\
\hline June 4 ..... & $15-16$ & & & December 2 & $20-22$ & & $24-27$ \\
\hline June $11 \ldots$ & $14-15$ & & & December & $21-23$ & & $24-27$ \\
\hline
\end{tabular}

In this State the farmer who a few years ago regarded turkeys as a nuisance which could not be tolerated has arrived at the conclusion that turkey raising is a source of great profit. The wives and children of farmers have taken up this industry vigorously. There is no live stock on the farm that is raised with less trouble and expense than turkeys. The most trouble encountered is during the first six weeks, after which they will hunt their own food. One hundred young turkeys can be maintained the first six weeks on $\$ 1$ worth of feed. Then add to this about $\$ 25$ worth of feed at fattening time and we have about all of the cash outlay. The income from the lot should be from $\$ 200$ to $\$ 250$. 


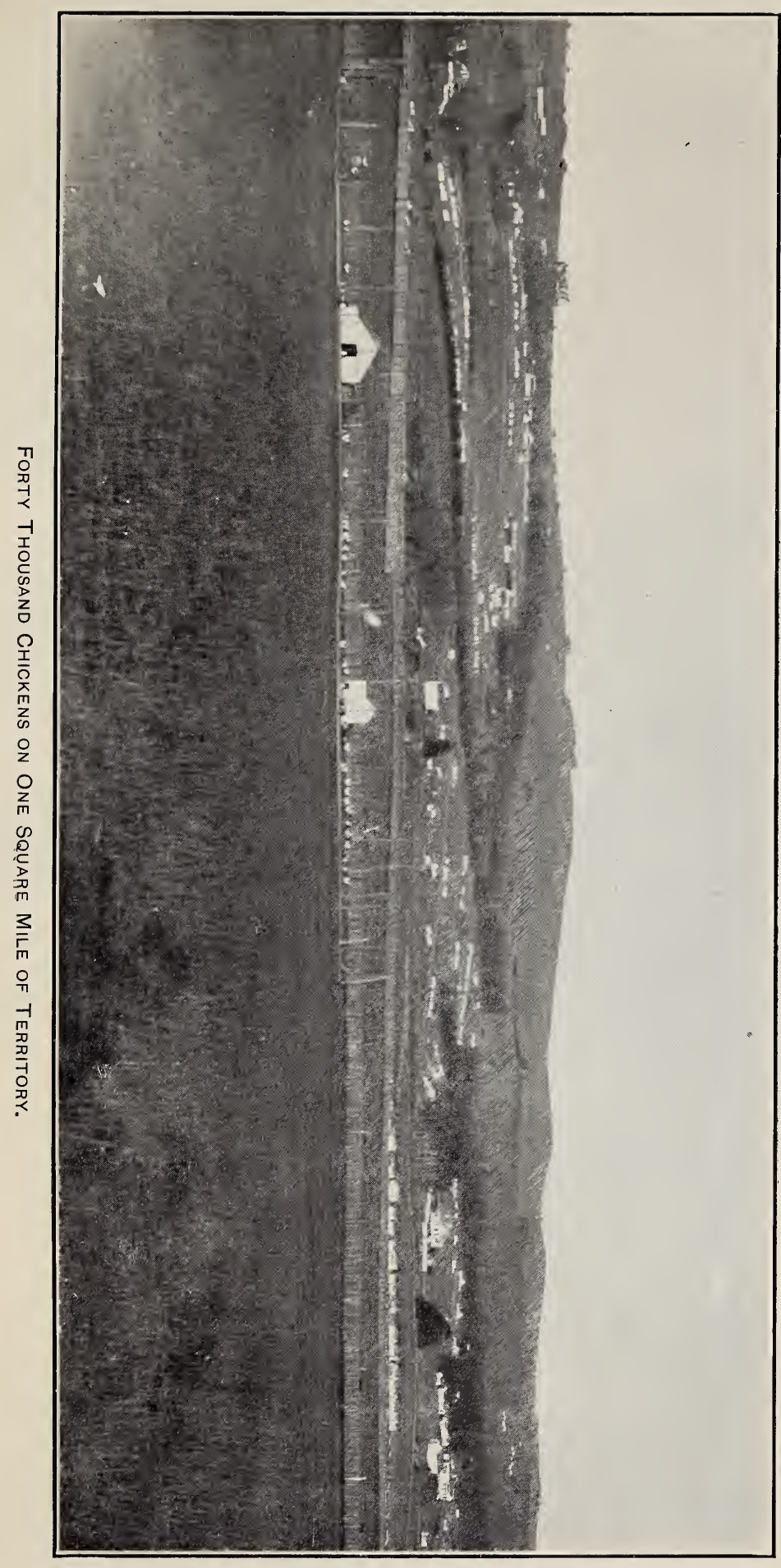


Digitized by the Internet Archive in 2016 


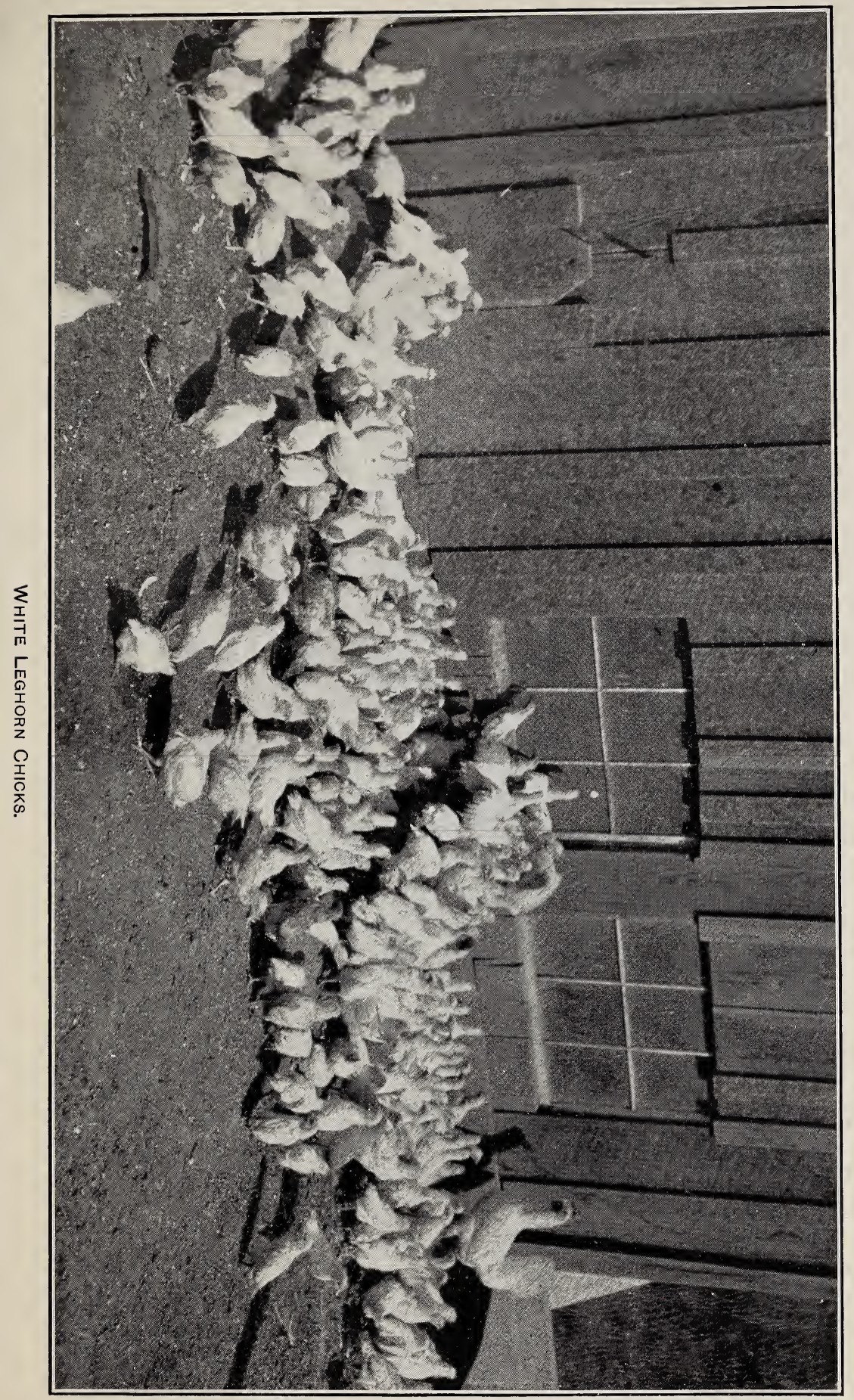





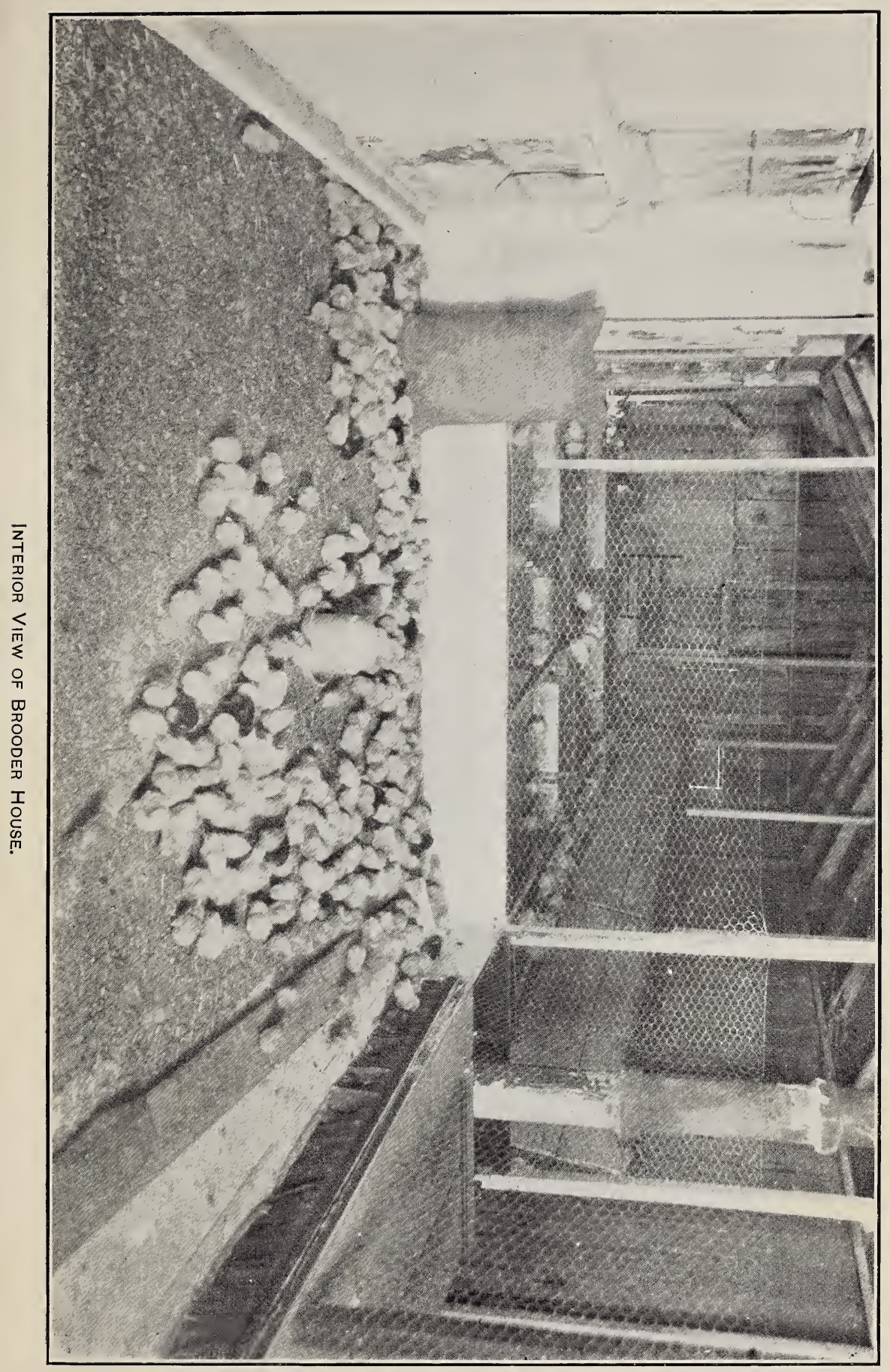


